\title{
Developing Technologically Responsive Reflective Learning Model for Z Generation Learners
}

\author{
Endah Tri Priyatni, Siti Cholisotul Hamiah, Pidekso Adi \\ Indonesian Department, Faculty of Letters \\ Universitas Negeri Malang \\ Malang, Indonesia \\ endah.tri.fs@um.ac.id
}

\begin{abstract}
Z$ Generation is a generation born and grows up with the internet. Generation $Z$ requires a learning model that is more than traditional learning. This study aims to develop a learning model for the Z-generation learners, which is called Technologically Responsive Reflective Learning. There are two main products developed, namely reflective learning model syntax and technology feature integrated to support the reflective learning process. The research was developed with R2D2 design, which has three development focuses, namely: (1) defining focus, (2) design and development focus, and (3) dissemination focus. Research data were in the form of comments, criticism, suggestions on the product, and the score of the product from expert teams, practitioners, and users of the product. The data were analyzed according to their domain to determine the product feasibility. Assessment aspects of experts and practitioners, which did not meet the eligibility were revised to fulfill the eligibility criteria. Research findings showed that after some improvements, this research product is very feasible to be implemented.
\end{abstract}

Keywords-learning model, reflective learning, technologically responsive, and Z-generation

\section{INTRODUCTION}

Z-generation is a generation born after 1995; they were born and grow up with the internet that has become the part of their lifestyle. Z-generation has the following lifestyles: (1) using smartphone 15.4 per week, (2) enjoying television shows for 13.2 hours per week, and its percentage increases $41 \%$ every 12 months, (3) conventional things are little interest to this generation, (4) its life requires technological intervention and a new way of delivering [1]

Z-generation is not a group of teenagers but it is a future generation that needs to be given serious attention. They are the activists who have big dreams; they are the tech-literate generation, they are the generation of snapshot and Instagram; they no longer use facebook and twitter; they are the mobile technology users; they are easy to adopt and adapt [2].

The ease of adopting and adapting leads to learning tasks with the question of what, when, and how which are no longer suitable for Z-generation learners because the answers will be easily obtained anywhere, anytime from various media by simply typing keywords on their smartphone. Learning tasks should force them to think reflectively. Learning for Z- generation learners should produce products that utilize the mobile technology and they are unique and the learning should prioritize to the visual display, be globally oriented, or promote local products to a global arena that inspires the world, promote the positive messages to create a comfortable circumstance in the world [2]. Z-generation learners need more learning models than just traditional learning; they require both reflective and technologically responsive learning models.

The reflective learning model was adopted from the thought of reflective thinking proposed by [3]. Dewey [3] defined reflective thinking as giving active, persistent, and cautious consideration of the beliefs or forms of knowledge and supporting the consequences arising from the giving of those considerations [3]. Mentoring activities, coworker involvement, and critical reflection on experience are the examples of current reflective thinking practice [4]. The results of reflective thinking can be the suggestions to find solutions, solve the difficulties experienced, utilize one suggestion to generate the new ideas or hypothesis and the beginning of finding observation or operate the instructions in collecting the factual material, extrapolate the ideas, or assumptions, or verify the truth of the hypothesis.

Dewey reflective thinking concept is widely used by experts to improve the learning process and outcomes. Reflective thinking is individual and dialogical [5]. Students who are learning, in essence, can also reflect on their learning experiences, what makes them unsuccessful or successful, what they feel, what are their advantages and disadvantages, whether they are happy with the learning activities being undertaken, and what solutions that are appropriate to improve the quality of the learning process and outcomes. Teachers can also conduct a dialogue to know the cognitive strategies of students in understanding or practicing something.

In individual reflection, students write down their learning experiences, both learning knowledge and practice aspects, then reflect on what is already understood, what is not understood, why they have not understood, what they learned, what makes the learning unsuccessful, and what to do to make improvements. Mobeley [6] called individual reflection a "conscious service learning" that requires participants to consider their individual identity and perspective, conscious reflection which can lead to an understanding of "individual's identity" in understanding or practicing something. 
The results of a case study conducted by [7] proved that by applying multimodal reflective learning to creative lectures, i.e. fashion, music, and dance, can encourage students to gain a deeper understanding and enable students to actively participate to reflect on their work, and be able to produce other creative works. The analyzed creative works can stimulate or trigger the emergence of inspiration to produce similar creative works. Higher education needs to develop students' reflective skills [8] to enable them to manage the gap between practice and the theory that they will face after they graduate.

Reflective learning model involves two high-level thinking skills, namely critical and creative thinking. The ability to think critically is used to reflect on the learning that has been done, what are the advantages and disadvantages. Creative thinking is done to find solutions that need to be done to make improvements or to produce new or transformed works based on the results of critical thinking that have been done.

The reflective learning model that combines two important skills and technologically responsive learning models is expected to address new challenges, demands, and needs in education, especially in the XXI Century. XXI century is marked by the revolution of knowledge and digital. The knowledge revolution demands critical and creative skills to cultivate and utilize a myriad of unstoppable knowledge and information. The digital revolution that has transformed the world and human life has brought new challenges, demands, and needs to the world of education, especially in learning, so it must be responded with reflective as well as technologically responsive models of learning.

The focus of this research is to develop a technologically responsive reflective learning model for Z-generation learners. The model is the embodiment of the approach, method/strategy, technique, and procedure that we chose [9]. A learning model describes the complete steps or syntax of learning from start to finish [10]. A learning model is designed based on a chosen learning approach, and accommodates one or more learning methods/strategies, even incorporates classroom management [11].

The learning model is characterized by phases containing steps to achieve specific goals derived from the theory/research outcomes, communication patterns between teachers and learners, the role of teachers and learners, and the tools supporting model implementation. Based on these characteristics, the development of the learning model in this study resulted in a product in the form of learning design which contains learning stages based on reflective thinking theory that is technologically responsive for Z-generation learners.

\section{RESEARCH METHODOLOGY}

This research uses development research design to develop a product in the form of technologically responsive reflective learning model for Z-generation learners, especially for preteacher of Indonesia language and literature of Z-generation. The designs of development research used were Recursive, Reflective Design and Development model or abbreviated as R2D2 [12], [13]. In the R2D2 model, there are three development focuses, namely (1) defining focus, (2) design and development focus, and (3) dissemination focus [13].

There are two main activities undertaken in the defining focus, namely (1) defining the product specifications and (2) defining the collaborative teams. Defining the product specifications aims to provide a guidance on the development of products. Product specifications are tentative, that means, the development process can be adjusted for product stability. Product specifications resulted in research in the form of a syntax of technologically responsive reflective learning applied in Informative Text Reading course in Indonesian Language and Literature Education Program, Faculty of Letters, State University of Malang. The collaborative team consists of (1) researchers, (2) team of experts, (3) practitioners, and (4) students.

The development stage was done by developing research product. The first product is a reflective learning model by describing each part, including (1) introduction, (2) theoretical basis of reflective learning model and responsive technology, (3) syntax of technologically responsive reflective learning model, (4) application of technologically responsive reflective learning model in writing review text, (5) application of technologically responsive reflective learning model in writing reflective essay texts, and (6) conclusion.

The second product is a website with its features to support the technologically responsive reflective learning model [14]. Technology is used not only for the delivery of learning content but also can be a facilitator to construct thoughts and knowledge, namely to: (1) help the learners to express and describe what they know, (2) reflect on what they learn and how they get it, 3) support the learners to make the internal meanings and negotiations, and (4) collaborate with peers to discuss, and comment.

The products that have been developed are packaged and disseminated in digital and printed form. Digital products are uploaded to a special website and are online. Printed products are published in monographs and disseminated in international and national seminars.

Product validation was performed by experts, who are competent in reading and designing learning models. The product tryout conducted in this development study consists of (1) practitioner and (2) prospective users. The practitioners involved were the lecturers of the Informative Texts Reading Course. Experts and practitioners' responses served as the basis for establishing product feasibility. The assessment aspects of experts and practitioners that had not met the eligibility were revised to fulfill the eligibility criteria. The expert/practitioner's criticism and suggestions were used to improve the product.

The tryout to users was done by involving one class of students of Language and Literature Studies Program of Universitas Negeri Malang (State University of Malang). The tryout process was done through the application of learning model. After the implementation of learning, the students were asked to provide responses, criticisms, and suggestions on the attractiveness and usefulness to improve the students' reading ability. The results of tryout to the students in the form of 
responses, criticisms, and suggestions were used to improve the product.

The data in this research were qualitative in the form of responses, suggestions, and criticism, from experts, practitioners, and college students, and quantitative data in the form of product feasibility scores from expert teams. The instruments of research were questionnaire and expert appraisal format. The data were analyzed by grouping the data based on research domain, interpretation, reflection, and inference. The domain analysis included the compatibility of learning syntax with the theoretical basis of reflective learning, the appropriateness of technological features to support the learning process, language exposure, and appearance. The product feasibility criteria can be seen in Table 1.

TABLE I. PRODUCT FEASIBILITY CRITERIA

\begin{tabular}{|l|l|}
\hline \multicolumn{1}{|c|}{ Range } & \multicolumn{1}{c|}{ Criteria } \\
\hline $3.26-4.00$ & Very feasible \\
\hline $2.51-3.25$ & Feasible \\
\hline $1.76-2.50$ & Feasible enough \\
\hline $1.00-1.75$ & Not feasible \\
\hline
\end{tabular}

\section{RESEARCH RESULTS}

The products of this development research are technologically responsive reflective learning model, technology features to support the reflective learning process, and product validation results. The descriptions of these three things are described below.

\section{A. Description of Technologically Responsive Reflective Learning}

One element of the learning model is the syntax of learning or learning stages. Some researchers have found a syntax of reflective learning, some of which are [7], [8], [15]. Bain [15] found five stages of reflective learning: (1) reporting, (2) responding, (3) relating, (4) reasoning, and (5) reconstructing. The five stages are called 5R. Barton and Ryan [7] adapted the five stages of reflective learning [15] into 4R, i.e.: (1) reporting and responding, (2) relating, (3) reasoning, and (4) reconstructing.

The syntax of technologically responsive reflective learning model was adapted from [7]. The adaptation was done by adding the technological features to support the reflective learning process in Informative Text Reading Course. The syntax of technologically responsive reflective learning model can be seen in Table 2 .

TABLE II. SYNTAX OF TECHNOLOGICALLY RESPONSIVE REFLECTIVE LEARNING MODEL

\begin{tabular}{|c|c|c|c|}
\hline No. & $\begin{array}{c}\text { Learning stages } \\
\text { (Syntax) }\end{array}$ & Learning Activities & Skills \\
\hline 1. & $\begin{array}{l}\text { Reporting and } \\
\text { responding }\end{array}$ & $\begin{array}{l}\text { Reporting a book that has been red and the reason of choosing the book. } \\
\text { Responding to the book's credibility by utilizing digital technology (google search) and } \\
\text { the following question guides. } \\
\text { Is the writer of the book an expert in their field? } \\
\text { Is the publisher credible? Is there any book ISBN? If the book is taken from the } \\
\text { internet, does it use the definite sites, such as the sites belonging to a particular } \\
\text { institution? } \\
\text { Are the references also included in the book? } \\
\text { Is the referral list credible/ reliable? } \\
\text { Is it clear when the reference is published or uploaded? }\end{array}$ & $\begin{array}{l}\text { Communication } \\
\text { Critical thinking } \\
\text { Curiosity }\end{array}$ \\
\hline 2. & Relating & $\begin{array}{l}\text { Reading the selected book thoroughly } \\
\text { Determining the book classification, popularity and quality from multiple sources by } \\
\text { utilizing the digital technology } \\
\text { Writing the results of the book quality in the form of a review text by utilizing a review } \\
\text { guideline } \\
\text { Uploading the review text on the website that has been provided, namely } \\
\text { www.membacaref.com } \\
\text { Asking the colleagues and lecturers to provide feedback, questions, comments, or } \\
\text { suggestions. }\end{array}$ & $\begin{array}{l}\text { Curiosity } \\
\text { Critical thinking } \\
\text { Creativity } \\
\text { Collaboration } \\
\text { Problem-solving } \\
\text { Communication }\end{array}$ \\
\hline 3. & Reasoning & $\begin{array}{l}\text { Rethinking (reflecting) the review text that has been produced } \\
\text { Explaining the advantages and disadvantages of the review text that has been produced } \\
\text { Rethinking the comments of the colleagues or lecturers on the review text that has been } \\
\text { produced }\end{array}$ & $\begin{array}{l}\text { Critical thinking } \\
\text { Collaboration } \\
\text { Problem-solving }\end{array}$ \\
\hline 4. & Recostructing & $\begin{array}{l}\text { Discussing and using the various options to improve the review text } \\
\text { Rewriting the review text based on the reflection results } \\
\text { Checking whether there is a plagiarism element in the review text by using the } \\
\text { www.google.com } \\
\text { Uploaded and reconstructed reviewer's text }\end{array}$ & $\begin{array}{l}\text { Critical thinking } \\
\text { Creativity }\end{array}$ \\
\hline
\end{tabular}


TABLE III. TECHNOLOGY FEATURES TO SUPPORT THE REFLECTIVE LEARNING PROCESS

\begin{tabular}{|c|c|c|}
\hline Feature & Definition & Skills \\
\hline $\begin{array}{l}\text { There is an interaction } \\
\text { between the users }\end{array}$ & $\begin{array}{l}\text { Allowing the users and observers to interact with } \\
\text { technology, upload, download, give comment } \\
\text { andcritique, suggest or answer the questions. }\end{array}$ & $\begin{array}{l}\text { Critical thinking } \\
\text { Collaboration } \\
\text { Problem-solving } \\
\text { Creativity } \\
\text { Communication }\end{array}$ \\
\hline Response is multimodal & $\begin{array}{l}\text { Technology can accept the uploads or user's responses in } \\
\text { verbal form (words, sentences, discourses) or images/ } \\
\text { photos, or audio-visuals. }\end{array}$ & $\begin{array}{l}\text { Creativity } \\
\text { Communication }\end{array}$ \\
\hline $\begin{array}{l}\text { The users can explore and or } \\
\text { create their work }\end{array}$ & $\begin{array}{l}\text { The users have the right to upload their works, edit, or } \\
\text { delete comments which they find unimportant. }\end{array}$ & $\begin{array}{l}\text { Critical thinking } \\
\text { Collaboration } \\
\text { Problem-solving } \\
\text { Creativity }\end{array}$ \\
\hline $\begin{array}{l}\text { Allowing the users to keep } \\
\text { writing for a long time }\end{array}$ & $\begin{array}{l}\text { The technology used can keep the users' works along } \\
\text { with its records in a long time (minimum } 1 \text { year). }\end{array}$ & $\begin{array}{l}\text { Critical thinking } \\
\text { Collaboration } \\
\text { Problem-solving } \\
\text { Creativity }\end{array}$ \\
\hline $\begin{array}{l}\text { Allowing the others to provide } \\
\text { a feedback }\end{array}$ & $\begin{array}{l}\text { The technology used allows the others who read it to } \\
\text { provide a feedback. }\end{array}$ & $\begin{array}{l}\text { Critical thinking } \\
\text { Collaboration }\end{array}$ \\
\hline $\begin{array}{l}\text { Available interactive test with } \\
\text { an immediate response }\end{array}$ & $\begin{array}{l}\text { There is a test for interactive-creative reading ability and } \\
\text { the test allows the system to automatically/quickly assess } \\
\text { through online media such as email. }\end{array}$ & $\begin{array}{l}\text { Critical thinking } \\
\text { Collaboration } \\
\text { Problem-solving } \\
\text { Creativity } \\
\text { Communication }\end{array}$ \\
\hline
\end{tabular}

\section{B. Description of Technology Features To Support Reflective Learning Process}

How are the technology-based learning features developed to support the reflective learning process? Technology-based learning features can be seen in Table 3 .

\section{Product Validation}

This research development product has been validated by a team of experts. Validation results can be seen in Table 4 . The products in the form of reflective learning models that are responsive to technology have also received qualitative input from the expert teams, practitioners, and students. These essential inputs, criticisms, suggestions, or comments can be seen in Table 5.

TABLE IV. THE RESULTS OF PRODUCT VALIDATION

\begin{tabular}{|l|l|l|l|}
\hline Evaluation Aspects & \multicolumn{1}{|c|}{ Aspects Indicators } & \multicolumn{1}{|c|}{$\begin{array}{c}\text { Results } \\
\text { (average) }\end{array}$} & Criteria \\
\hline Stages of learning & $\begin{array}{l}\text { The suitability of the learning model stage with the } \\
\text { theoretical basis of reflective learning }\end{array}$ & 3.67 & Very feasible \\
\hline & Clarity of learning stages & 3.67 & Very feasible \\
\hline & Easy implementation & 3.33 & Very feasible \\
\hline & Sufficient time & 3.67 & Very feasible \\
\hline Digital Technology & $\begin{array}{l}\text { The suitability of technology is integrated in the syntax of } \\
\text { learning to support the learning process }\end{array}$ & 3.67 & Very feasible \\
\hline & $\begin{array}{l}\text { The suitability of technology is integrated in the syntax of } \\
\text { learning to improve critical thinking and creative writing } \\
\text { skills. }\end{array}$ & 3.67 & Very feasible \\
\hline & $\begin{array}{l}\text { The compatibility of technologies that are integrated in the } \\
\text { syntax of learning is to foster the ability of collaboration } \\
\text { and communication }\end{array}$ & 3.67 & Very feasible \\
\hline & $\begin{array}{l}\text { The compatibility of technologies that are integrated in the } \\
\text { syntax of learning is to create a meaningful learning }\end{array}$ & 3.33 & \\
\hline
\end{tabular}


TABLE V. FEEDBACK, CRITICISM, AND OR SUGGESTION FROM THE COLLABORATIVE TEAM

\begin{tabular}{|c|c|c|c|}
\hline Evaluation Aspects & Aspects Indicators & Comment/Input/Criticism/Suggestion & Following up \\
\hline \multirow[t]{5}{*}{ Stages of learning } & $\begin{array}{l}\text { The suitability of the } \\
\text { learning model stage with } \\
\text { the theoretical basis of } \\
\text { reflective learning }\end{array}$ & $\begin{array}{l}\text { The reflective dimension which is less } \\
\text { prominent-needs to be strengthened in } \\
\text { every learning stages } \\
\text { The student's habits that need to be } \\
\text { trained reflect the process and learning } \\
\text { outcomes. }\end{array}$ & $\begin{array}{l}\text { Highlighting the reflective } \\
\text { dimension in each learning } \\
\text { stages } \\
\text { Increasing the reflection } \\
\text { activity in each learning stages }\end{array}$ \\
\hline & Clarity of learning stages & $\begin{array}{l}\text { Additional considerations may be given } \\
\text { to each assignment so that students } \\
\text { keep in mind the rules of spelling and } \\
\text { punctuation. }\end{array}$ & $\begin{array}{l}\text { Added instructions to pay } \\
\text { attention to the rules of spelling } \\
\text { and punctuation }\end{array}$ \\
\hline & $\begin{array}{l}\text { The suitability of } \\
\text { technology is integrated in } \\
\text { the syntax of learning to } \\
\text { improve the critical } \\
\text { thinking and creative } \\
\text { writing skills. }\end{array}$ & $\begin{array}{l}\text { His creative abilities are optimized with } \\
\text { more writing tasks. } \\
\text { The creative writing activity needs to } \\
\text { be maximized. } \\
\text { Theability to critically comment is not } \\
\text { deep enough }\end{array}$ & $\begin{array}{l}\text { Adding the writing task, ie } \\
\text { writing a reflective poem } \\
\text { Giving a reflective guide for } \\
\text { reflection to focus on the } \\
\text { essential and deep aspects }\end{array}$ \\
\hline & $\begin{array}{l}\text { Ease of interaction system } \\
\text { based on digital } \\
\text { technology in the form of } \\
\text { website-to be operated. }\end{array}$ & $\begin{array}{l}\text { Feature test item can not be opened } \\
\text { directly, the system prompts to install } \\
\text { plungin first }\end{array}$ & Improved the test item fiture \\
\hline & $\begin{array}{l}\text { The compatibility of } \\
\text { technologies that are } \\
\text { integrated in the syntax of } \\
\text { learning to foster the } \\
\text { ability to collaborate and } \\
\text { communicate }\end{array}$ & $\begin{array}{l}\text { Interactions between students should be } \\
\text { improved } \\
\text { A discussion of students can be } \\
\text { developed through mutual reflection } \\
\text { activities related to the knowledge } \\
\text { gained during the lectures }\end{array}$ & $\begin{array}{l}\text { Every student is required to } \\
\text { reflect the friend's work }\end{array}$ \\
\hline Language & $\begin{array}{l}\text { The effectiveness of the } \\
\text { language usage on the } \\
\text { website }\end{array}$ & $\begin{array}{l}\text { Considering the effectiveness of the } \\
\text { language usage. } \\
\text { Examples of the text presented are } \\
\text { maximally free from errors. }\end{array}$ & $\begin{array}{l}\text { Fixed use of ineffective } \\
\text { language, including spelling } \\
\text { and punctuation }\end{array}$ \\
\hline Website Display & $\begin{array}{l}\text { Accuracy of these aspects: } \\
\text { selection of images, fonts, } \\
\text { layout, and color } \\
\text { combinations }\end{array}$ & $\begin{array}{l}\text { It needs a more contrasting color choice } \\
\text { between the text and the background. } \\
\text { The web backlight seems too wide, not } \\
\text { included in one whole screen } \\
\text { (especially for miniature laptops like } 10 \\
\text { inches). }\end{array}$ & $\begin{array}{l}\text { The website display is fixed in } \\
\text { accordance with the } \\
\text { suggestions }\end{array}$ \\
\hline
\end{tabular}

\section{RESUlt AND DISCUSSION}

The validation data indicate that the technologically responsive reflective learning products developed in this study are very feasible to be implemented in classroom learning, especially in reading course. The first advantage of this research product is reflective learning model is combined with technology. Technology features are integrated to support the learning process. This is in line with the opinion of [14] stating that the technology used in learning can be a partner and support the process of learning rather than just as a tool to deliver the learning materials. Technology developed in this study is in the form of a website, namely www.membacaref.com and also takes the advantage of Google to search the data and also Google.com for plagiarism test.

The use of technology in the learning process has been clearly reflected in every stage of learning. In stage 1 (reporting and responding), technology plays a role to check the credibility of the book. In stage 2 (relating), technology plays a role in searching book and author data to determine the classification and the popularity of the book, uploading the review text and being the media for discussion, the interaction between students-students, and the studentslecture. In stage 3 (reasoning), technology acts as a tool for reflection on review text that has been uploaded on the website and also comments from friends and visitors of the website. In stage 4 (reconstructing), technology plays a role to check plagiarism and a tool to display the review text that has been reconstructed.

Thus, the technology integrated in this reflective learning model has many roles. First, technology plays a role to support the learners in constructing knowledge, which is to represent learners' ideas, understanding, and beliefs and technology to produce and organize multimedia-based knowledge. The learners can utilize the technology to present their ideas, and understanding in the form of PowerPoint, video, flash, a blog on the online or offline web. The learners can upload their works to their blogs. Second, technology is used to access the information and references needed in learning and at the same time technology can be used as a means to compare the perspectives, beliefs, or views from various sources. The third role, technology also works as a social media to support the learning process to collaborate with fellow friends, to discuss, and comment. The fourth 
role, technology as an intellectual partner to support the learning through reflection to: (1) help the learners to express and describe what they know, (2) reflect on what they learn and how they get it, (3) support the learners to make the meaning and internal negotiation, and (4) support the conscious thought [14].

A second advantage, this technologically responsive reflective learning model also serves to develop the essential skills that learners need in the $21 \mathrm{st}$ century, they are, collaborative, communicative, critical, creative, and problem-solving skills according to their context [16]. These functions are clearly illustrated in every learning stage. In stage 1 (reporting and responding), the developed aspects were communication skill and critical thinking. The skills of communicating both orally and in written were developed to report the books read along with the reasons for their selection. Critical thinking skills are used to respond to the credibility of the book being reviewed. In stage 2 (relating), there were five important skills that were trained, namely critical thinking, creativity, collaboration, problem-solving, and communication. Critical thinking skills are needed to determine the classification of the book and assess the quality of the book, the creative skills needed to produce a review text and upload it on the web of membacaref.com, and the collaborative and problem-solving skills which are necessary to provide comments, criticisms and suggestions on friends' works, lecture, or visitors of the web. In stage 3 (reasoning), it was necessary to have critical thinking skills to rethink/reflect on the reviews that have been prepared and also comments from friends, lecture, and web visitors. In stage 4, the skills developed were critical thinking and creativity. Critical thinking skills are used to discuss and use various options to improve the review work that has been compiled, as well as to check the plagiarism, and creative skills that are significant to reconstruct the review text.

\section{CONCLUSIONS}

Based on the above explanation, it can be concluded that technologically responsive reflective learning model is very feasible to be implemented in learning, especially for reading course. There are two product advantages developed in this research. First, the reflective learning model combined with technology plays an important role in supporting the learning process, which is to represent, organize, produce ideas, also function as social media to support the learning process to collaborate with fellow friends, to discuss, comment and as an intellectual partner to support the learning through reflection. Second, this technologically responsive reflective learning model also works to develop the essential skills that learners need in the 21st century: collaborating, communicating, critical and creative thinking, and problems solving in context.
Based on the results, it is recommended to implement this learning model in the classroom to facilitate the growth of critical and creative thinking, collaborative and communicative skills and simultaneously to develop the social skills, cultivate the engagement of Z-generation learner. The generation that literate in technology needs a democratic and independent learning model and.

\section{ACKNOWLEDGEMENTS}

The writer would like the Research Grants Program of Higher Education IDB Project State University of Malang, Indonesia, in the year of 2016-2017, that has funded this research.

\section{REFERENCES}

[1] J. Glum, "Marketing to Generation Z: Millennials move aside as brands shift focus to under-18 customers," International Business News., 2015.

[2] G. Jati, "Teknologi, Literasi, dan Pembelajaran Bahasa untuk Generasi Z." 2016.

[3] J. Dewey, How we think. Buffalo. New York: Prometheus Books, 1933.

[4] B. Larrivee, "Transforming Teaching Practice: Becoming the critically reflective teacher," Reflective Pract., vol. 1, no. 3, pp. 293 307, 2000.

[5] P. E. Black and D. Plowright, "A multi-dimensional model of reflective learning for professional development," Reflective Pract., vol. 11, no. 2, pp. 245-258, 2010.

[6] T. Stewart and N. Webster, Exploring cultural dynamics and tensions within service-learning. IAP, 2011.

[7] G. Barton and M. Ryan, "Multimodal approaches to reflective teaching and assessment in higher education," High. Educ. Res. Dev., vol. 33, no. 3, pp. 409-424, 2014.

[8] M. Ryan and M. Ryan, "Theorising a model for teaching and assessing reflective learning in higher education," High. Educ. Res. Dev., vol. 32, no. 2, pp. 244-257, 2013.

[9] E. T. Priyatni, "Pengembangan Bahan Ajar Membaca Kritis Berbasis Intervensi Responsif dengan Multimedia," 2011.

[10] B. Joyce, M. Weil, and E. Calhoun, Models of teaching. Pearson, 2009.

[11] A. Sudrajat, "Pengertian pendekatan, strategi, metode, teknik, taktik, dan model pembelajaran," 2008.

[12] B. Colon, K. A. Taylor, and J. Willis, "Constructivist Instructional Design: Creating a Multimedia Package for Teaching Critical Qualitative Research," Constr. Instr. Des. CID, vol. 5, no. 1/2, pp. 443-472, 2000

[13] J. Willis, "A recursive, reflective instructional design model based on constructivist-interpretivist theory," Educ. Technol., vol. 35, no. 6, pp. 5-23, 1995.

[14] H. Jonassen, J. Howland, J. Moore, and R. . Marra, Learning to Solve Problems with Technology. Columbus, Ohio: Pearson Education., 2003.

[15] J. D. Bain, R. Ballantyne, C. Mills, and N. C. Lester, Reflecting on practice: Student teachers' perspectives. Post Pressed, 2002.

[16] "New Vision for Education: Fostering Social and Emotional Learning through Technology," Geneva,Switzerland, 2016. 